Association; London: Chartered Institute of Library and Information Professionals, 2010).

2. Charles A. Cutter, Rules for a Printed Dictionary Catalogue (Washington, DC: Government Printing Office, 1876).

3. International Federation of Library Associations and Institutions Study Group on the Functional Requirements for Bibliographic Records, Functional Requirements for Bibliographic Records: Final Report (The Hague: International Federation of Library Associations and Institutions, 2009), accessed Sept. 26, 2012 , http://archive.ifla.org/VII/s13/frbr/ frbr_2008.pdf.

Academic Archives: Managing the Next Generation of College and University Archives, Records, and Special Collections. By Aaron D. Purcell. New York: Neal-Schuman, 2012. 315 p. $\$ 95$ softcover (ISBN: 978-1-55570-769-9).

In Academic Archives, Purcell takes a broad approach to a small area of the library world, addressing many aspects of the operations within the narrow purview of an academic archives. He divides the book into three parts, with part 1 describing the current state of archives in an academic setting. In this section, he begins by outlining the steps required to obtain a professional position in an academic archives, the mission of academic archives, and the role of these archives under the larger umbrella of special collections. Part 1 is observational in tone, looking at archives from an external perspective. In part 2, Purcell pursues a more operational approach. This part, which is nearly two-thirds of the book, is a discussion of the specific tasks required to build or update an academic archives program. Here Purcell also describes in detail the different aspects of operating an academic archives, including acquisition, processing, reference services, and digitization. Part 3 consists of a single chapter, focusing on emerging trends and the next generation of academic archives. To balance the other two sections, more weight should have been given to this area-particularly because the subtitle of the book specifically addresses the future of these collections rather than the present.

In terms of physical format, the book is well organized. Purcell breaks up the sections nicely so that the reader does not become encumbered by long sections of weighty prose and can proceed directly to specific sections of interest. He also has inserted grey blocks throughout the text, containing bulleted lists that highlight important concepts in the surrounding paragraphs. This feature is helpful for the casual reader who is simply skimming the text for the high points or for those who are interested in previewing the content of the book before investing the time and effort to read further.

Purcell includes occasional photographs and diagrams to add visual interest, but these are sporadic and not particularly dynamic. Some of the loss in impact may be because the images are black and white rather than color. Although color illustrations may have been cost-prohibitive, the lack of color prevents the level of detail necessary to appreciate the content of the photographs. As a result, some of the images are more useful than others. His textual descriptions of complicated processes are thorough and effective, however, which make the images superfluous.

Part 1 combines three very different aspects of academic archives under the umbrella of "Archives and the Academic Environment." The first chapter targets one of the primary audiences for which this book would be appropriate-prospective archivists. Chapter 2 is more of a survey of what academic archives are, including a substantial section on the role that technology plays in the modern academic library. Chapter 3 offers an overview of the history of special collections, followed by an examination of their structure today and the types of materials one might expect to find. Purcell also dedicates several pages to the next generation and future directions for special collections, which is explored in greater length in part 3.

In contrast to part 1 , which examines established academic archives as they currently exist, part 2 addresses issues associated with updating or building new programs. The first two chapters of part 2 (chapters 4 and 5) operate on higher administrative levels, focusing on mission and vision building for the archives and institutional records management. Although useful, the concepts put forth are more policy-driven than procedural and require the would-be archivist to operate on a different level of responsibility, addressing the role of the archives within the larger academic environment. This is a role more likely to be assumed by a senior member of the archives' staff, who presumably is already familiar with the specifics of archival operations and therefore unlikely to read this introductory text.

The greatest strength of this book can be found in part 2-in particular, chapters 6 through 9, which offer a systematic guide to working in an academic archives. From collection development to processing, research services, and digitization, Purcell provides the reader with a true sense of operations in this type of environment. His descriptions are thorough, and he uses terminology that allows the layperson to follow the course of the various processes, which means that even those activities that can be extremely complicated, like the physical arrangement of a collection or the creation of a finding aid, are well explained.

Purcell's approach is ambitious in both audience and scope of content. As he states in the preface, he targets the book to a wide-ranging audience, including archivists, information professionals, library directors, historians, academics, and prospective archivists, 
and he incorporates several topic themes. The diversity of his intended audience alone created a challenge because the needs of each group are likely to be dramatically different, and Academic Archives does not seem useful to all of the reader groups mentioned above. Because parts 1 and 2 function differently, they have different target audiences. The most appropriate audience for part 1 is the current or prospective student considering a career in the field. Purcell provides a good overview of the preparation necessary to obtain a position in an archive, as well as the continuing professional development that is often expected. Part 2 is more appropriate for an individual who is currently working in an archive or someone planning to build a new academic archives department. If a more seasoned professional can be persuaded to explore this book, which initially might seem a bit introductory, they can take advantage of the useful suggestions for building and growing their archives programs more effectively. Finally, while both major parts of the book are useful to the respective audiences they serve, Purcell may want to consider a future project in which he separates these sections and expands them into two new books.-Jennifer $K$. Sheehan(Jennifer.sheehan@unt.edu), University of North Texas, Denton, Texas.

\section{Statement of Ownership, Management, and Circulation}

Library Resources \& Technical Services, Publication No. 311-960, is published quarterly by the Association for Library Collections \& Technical Services, American Library Association, 50 E. Huron St., Chicago (Cook), Illinois 60611-2795. The editor is Peggy Johnson, University of Minnesota, 499 Wilson Library, 309 19th Ave. South, Minneapolis, MN 55455. Annual subscription price, \$85.00. Printed in U.S.A. with periodicalsclass postage paid at Chicago, Illinois, and at additional mailing offices. As a nonprofit organization authorized to mail at special rates (DMM Section 424.12 only), the purpose, function, and nonprofit status of this organization and the exempt status for federal income tax purposes have not changed during the preceding twelve months.

(Average figures denote the average number of copies printed each issue during the preceding twelve months; actual figures denote actual number of copies of single issue published neared to filing date: July 2012 issue.) Total number of copies printed: average, 5,124; actual, 4,960. Paid distribution outside the mails including sales through dealers and carriers, street vendors, counter sales, and other paid distribution outside the USPS: average, 390; actual, 367. Total paid distribution: average, 4,543; actual, 4,352. Free or nominal rate copies mailed at other classes through the USPS (e.g. First-Class mail): average, 0; actual, 0. Free or nominal rate distribution outside the mail (carriers or other means): average, 171; actual, 171. Total free or nominal rate distribution: average, 175; actual, 173. Office use, leftover, unaccounted, spoiled after printing: average, 406; actual, 435. Total: average, 5,124, actual, 4,960. Percentage paid: average, 96.29; actual, 96.18.

Statement of Ownership, Management and Circulation (PS Form 3526, September 2007, for 2007/2008) filed with the United States Post Office Postmaster in Chicago, October 1, 2012. 